David $C$. Wheelock is a senior economist at the Federal Reserve Bank of St. Louis. Paul W. Wison is associate protessor of economics at the University of Texas at Austin.

\title{
Can Deposit Insurance Increase the Risk of Bank Failure? Some Historical Evidence
}

\begin{abstract}
政 WOAN LOSSES ASSOCIATED WITH declines in energy and agricultural prices, and the collapse of commercial real estate markets were the proximate cause of the high number of bank and savings and loan (S\&L) failures of the past 12 years. Many researchers also blame government policies, however; such as restrictions on branch banking and limitations on the services that banks and S\&Ls may offer. Such restrictions hamper diversification, thus leaving depository institutions particularly vulnerable to downturns in the regions which they serve.
\end{abstract}

Deposit insurance has probably been the most criticized government policy related to bank and S\&L failures. Many economists believe that deposit insurance encourages banks and S\&LS to take excessive risks, thereby increasing their chance of failing.'
This article investigates empirically the connection between deposit insurance and bank failure. Today, virtually all banks are insured by the Federal Deposit Insurance Corporation (FDIC) and, consequently, isolating the effects of insurance from other regulations and exogenous economic conditions that affect bank performance is difficult. We study the effects of deposit insurance by drawing on historical evidence from a voluntary insurance regime that operated in Kansas between 1909 and 1929. Because membership in the Kansas deposit insurance system was optional, we are able to compare insured and uninsured banks facing otherwise similar regulations and economic conditions in a way not possible with modern data. We estimate a model of bank failure to test for the impact of insurance on the likelihood of failure. ${ }^{2}$ We find that insured banks were less well capitalized and, in some years, less liquid
1Kane (1989) examines the problems of the $\mathrm{S} \& \mathrm{~L}$ industry and the rote of government policy. Mishkin (1992), Keeley (1990) and ODriscoll (1988) discuss the relationship between deposit insurance and bank failures in the 1980 s.

aWheelock (1992b) also investigates how deposit insurance affected the probabitity of falure for Kansas banks in this era, but employs a different methodology and somewhat different data. Wheelock and Wilson (1993) use the same data set as the present study, but while considering the effects of insurance, locus largely on whether or not meas- ures of managerial inefficiency help distinguish failing from surviving banks. Grossman (1992) also investigates the effects of deposit insurance by comparing insured and uninsured S\&Ls during the 1930s. 
than uninsured banks, and that capitalization and liquidity were important determinants of failure.

The next section discusses how deposit insurance might increase the likelihood of bank failure. Next, we describe the Kansas deposit insurance system and the effects of a collapse of commodity prices in 1920 on commercial banks. The final sections develop the econometric methodology used to model failure, specify the model, and present results and conclusions.

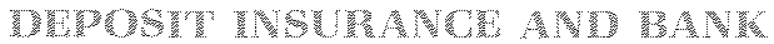

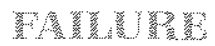

Federal deposit insurance was enacted in response to the bank failures of the Great Depression. Thousands of banks failed from 1930 to 1933 , wiping out the funds of depositors, producing a collapse of the money supply, increasing the costs of intermediation and interfering with the clearing of payments. ${ }^{3}$ Although large banks and many economists vigorously opposed deposit insurance, and President Franklin Roosevell was reluctant to accept it, Congress deemed deposit insurance necessary to protect small, unsophisticated depositors from losses due to bank failures, and the payments system from a wholesale banking collapse like that of $1930-33 .^{4}$

Until the 1980 s, deposit insurance was generally hailed for eliminating the possibility of widespread bank failures. ${ }^{5}$ Merton (1977) and Kareken and Wallace (1978) showed, however, that when insurance premiums are unrelated to the expected cost of failure to the insurance system, banks have an incentive to take greater risks than they otherwise would. Because depositors are protected in the event of bank failure Ito the limit of insurance coveragel, they have little or no incentive to monitor their banks' activities or to demand risk premiums on deposit interest rates. Deposit insurance thus raises the expected return to banks from investing in risky loans and investments and encourages them to substitute debt, in the form of insured deposits, for equity. Consequently, unless regulations inhibit risk-taking, the presence of deposit insurance could lead to more bank and S\&L. failures than there would otherwise be.

Many economists blame deposit insurance, coupled with inadequate regulation and supervision, political interference and a failure by regulators to promptly close insolvent institutions, for the high number of S\&L failures and bankruptcy of the Federal Savings and Loan Insur. ance Corporation during the 1980s. ${ }^{6}$ The banking industry's problems were, by comparison, less notorious. Banks faced higher capital requirements and were more stringently supervised than S\&.Ls, which lessened banks' incentive and ability to take excessive risks. But deregulation of deposit interest rates, initiated by the Depository Institutions Deregulation and Monetary Control Act (DIDMCA) of 1980 , the gradual removal of barriers to branch banking, more liberal chartering polices and increased competition from foreign banks and from nonbank financial institutions, all worked to lessen charter values and increase the incentive for banks (as well as S\&.Ls) to take greater risks. ${ }^{\top}$ Moreover, in 1980, deposit insurance coverage was increased from $\$ 40,000$ per account to $\$ 100,000$ for both banks and S\&.Ls, while the failure resolution policy known as "too-big-to-fail" effectively extended insurance to all deposits at the largesi banks, thereby enhancing their incentive to take risks."

As is all too often the case, the bank and thrift debacle of the $1980 \mathrm{~s}$ stemmed in part from the failure of policy makers to heed lessons from the past. Flood (1992) argues that when deposit insurance legislation was being considered in 1933, policy makers understood the temptation that insurance gives bankers to take excessive risks. Accordingly, coverage was

\footnotetext{
3Studies of the causes and effects of bank failures during the Depression are too numerous to list. Friedman and Schwartz (1963), however, is the seminal investigation of the impact of bank failures on the money supply, and Bernarke (1983) is the most important investigation of nonmonetary effects of bank falures.

${ }^{4}$ Golembe (1960) and Flood (1992) investigate the rationale for federal deposit insurance.

sFor example, see Friedman and Schwartz (1963, pp. 434-42).

6For example, see Kane (1989).
}

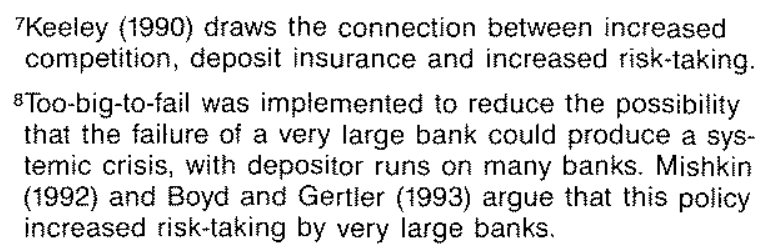
that the failure of a very large bank could produce a systemic crisis, with depositor runs on many banks. Mishkin (1992) and Boyd and Gertler (1993) argue that this policy increased risk+taking by very large banks. 
limited to $\$ 2,000$ per account and regulations were imposed to constrain risk-taking. Deposit interest rate ceilings prevented weak institutions from growing rapidly by bidding up interest rates, and regulators gave bankers added incentive to act conservatively by limiting the issuance of new bank charters. Many of the sources of increased competition for banks and S\&Ls that had emerged by 1980 , such as money market mutual funds and the commercial paper market, were the product of technological changes that could not be foreseen in $1933 .{ }^{3}$ But deregulation of bank and $S \& L$ deposits and the expansion of deposit insurance coverage at a time when the industry was facing increased competition contradicted the regulatory principle that underlay deposit insurance legislation in 1933.

The insights that policy makers had in 1933 about deposit insurance came party from prior state experiences with deposit insurance. Six states had experimented with insurance in the pre-Civil War era, as did eight others between 1908 and $1930 .{ }^{10}$ None of the 20 th-century systems was able to fully protect depositors of failed banks from loss, and each closed before the onset of the Great Depression. The commod ity-price collapse of 1920-21 triggered a wave of bank failures throughout the Midwest and the South, including seven of the eight states with deposit insurance. Although loan losses associated with the decline of state incomes was the proximate cause of bank fallumes, insured banks generally suffered higher failure rates than uninsured banks facing similar exogenous condi- tions. "Contemporaries believed that deposit insurance had contributed to the high number of fatures because it protected incompetent and dishonest bankers from market discipline. ${ }^{12}$ In the following sections, we investigate empirically how deposit insurance might have contributed to the failure of banks operating under the deposit insurance system of Kansas during the 1920s. We study this case because just three of the eight state insurance systems had optional membership for state-chartered banks and, hence, permit comparison of insured and uninsured banks facing otherwise similar conditions. Of these, only the Kansas system lasted for many years with a large number of banks electing to join the system and a significant number remaining uninsured.

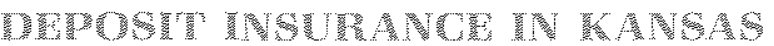

The Kansas deposit insurance system began operation in June 1909 and officially closed in 1929. Kansas was the second state to enact insurance legislation following the Panic of 1907 , and was motivated partly by the adoption of an insurance system by Oklahoma in $1908 .^{13} \mathrm{In}$ contrast to the oklahoma system, in which all state-chartered banks were required to carry insurance, the Kansas system was made optional for state banks because of complaints that insurance forces conservatively managed banks to insure depositors of banks that are more likely to fail. ${ }^{+4}$ The state of Kansas, like other states with deposit insurance systems, did not guarantee in surance payments. In contrast to the experience
9See Wheelock (1993).

10The 20th-century states and the years in which their insurance systems operated are Oklahoma (1907 23), Texas (1909-25), Kansas (1909-29), Nebraska (1909-30), South Dakota (1909-31), North Dakota (1917-29), Washington $(1917-29)$ and Mississippi (1914-30). Cooke (1909), Robb (1921), American Bankers Association (1933), Federal Deposit Insurance Corporation (1956) and Calomiris (1989) compare the features and performance of the systems.

11 Thies and Gerlowski (1989) and Alston, Grove and Wheelock (1994) find that a state's bank failure rate durting the 1920 s was higher if it had a system of deposit insurance, holding constant other possible causes of failure. Wheelock (1992a) reports similar evidence at the county level for Kansas.

12Commenting about the effects of the Kansas deposit insurance system, Harger (1926, p. 278) wrote that insurance "gave the banker with little experience and careless methods equality with the manager of a strong and conservative institution. Serene in the confidence that they could not lose, depositors trusted in the guaranteed bank. With increased deposits, the bank extended its loans freely." See also American Bankers Association (1933), Association of Reserve City Bankers (1933) and Robb (1921) for contemporary views about insurance.

t3Robb (1921) describes previous attempts to enact deposiz insurance legislation in Kansas and other states, and notes that Kansas banks located near the Oklahoma border were especially strong proponents of deposit insurance in Kansas (pp. 107-12).

${ }_{14}^{4}$ The Comptroler of the Currency ruled in 1908 that national banks could not join state deposit insurance systems. 
with federal insurance in the $1980 s_{\text {, }}$ depositors, not taxpayers, suffered from any insurance fund deficiencies. ${ }^{15}$

Kansas banks were required to operate for at least one year and undergo an examination by state authorities before being admitted into the insurance system. ${ }^{16}$ Insured banks were also required to maintain total capital of at least 10 percent of total deposits, and surplus and undis. tributed profits of at least 10 percent of total capital. ${ }^{r}$ At first, deposit insurance was restricted to noninterest bearing accounts, savings deposits of $\$ 100$ or less, and time deposits of between six and 12 months malurity. Banks with insured deposits were not permitted to pay more than 3 percent interest on any deposit, whether insured or not. ${ }^{18}$ Regulations were relaxed in 1911; insurance was extended to all deposits not otherwise secured, including savings accounts in excess of $\$ 100$, and the state banking commissioner was given authority to adjust interest rate ceilings as he deemed appropriate.

Insured banks were assessed annual premiums equal to $1 / 20$ of 1 percent of their insured deposits less total bank capital. Although a bank could reduce its premium by increasing its capital, the saving was small. A bank with $\$ 100,000$ of insured deposits and $\$ 10,000$ of capital was assessed an insurance premium of $\$ 45$, whereas a bank with $\$ 15,000$ of capital had a premium of $\$ 42.50$. Additional premiums could be assessed to cover shortfalls in the insurance fund, but total annual premiums were capped at $1 / 4$ of 1 percent of insured deposits less capital. Banks also were required to place cash or eligible bonds with the state banking commissioner equal to 0.5 percent $(\$ 500$ minimum) of their insured deposits to guarantee insurance premium payment. Banks could withdraw from the insurance system at any time, but remained liable for any premiums needed to reimburse depositors of banks which failed while the withdrawing bank was insured, including the six months following notice of withdrawal.

Deposit insurance proved popular in Kansas, and before 1920 the deposits of insured banks grew more rapidly than those of uninsured state and national banks. Figure 1 plots the participation rate of all Kansas banks and of those eligible for deposit insurance. Figure 2 illustrates the shares of all bank and eligible bank deposits held by insured banks. "The percentage of the state's bank deposits held by insured banks peaked in 1921 at 43.8 percent, and membership in the system peaked at 65.6 percent of eligible banks in 1923. In that year, 681 banks, holding $\$ 168$ million of deposits, belonged to the insurance system, while 357 state banks, holding $\$ 64$ million of deposits, did not.

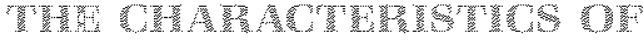

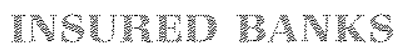

This section identifies some important differences between insured and uninsured banks that may explain why the failure rate of insured banks exceeded that of uninsured banks.

If depositors believe that they will be protected from loss in the event of bank failure, they will be willing to accept a lower rate of return on their deposits than they would in the absence of such protection. Because it lowers the cost of deposits, deposit insurance encourages banks to rely more heavily on deposits to finance their activities, as opposed to equity and nondeposit liabilities, than they otherwise would Economic theory suggests that banks also will choose to hold riskier assets when deposits are insured. $\approx$ Insured banks in Kansas had a higher failure rate than uninsured banks, which might have been caused by "moral haz. ard"' that is, by high-risk behavior encouraged by deposit insurance. Alternatively, because risky banks would stand to gain the most from insurance in terms of lower deposit costs, the
15Mississippi, however, ultimately issued bonds to retire the deficit of its insurance system.

${ }^{16}$ The requirement of one year of operation was vaived if no other bank in the applicant's town was an insurance system member.

17The former requirement was eliminated in 1917. Warburton (1958, p. 21) argues that, if maintained and enforced, the requirement could have prevented much of the rapid growth of banks that ultimately resulted in large losses to the insurance system.
${ }^{18}$ For comparison, the annual average interest rates on prime four-six month commercial paper and on call loans in 1909 were 4.69 and 2.71 percent, respectively.

19 All banks include those with federal charters, trust companies and unincorporated banks. The source of these data is the FDIC (1956, p. 68).

20See Merton (1977) of Kareken and Walace (1978). 
Figure 1

Proportion of Banks Participating in the Deposit Insurance System

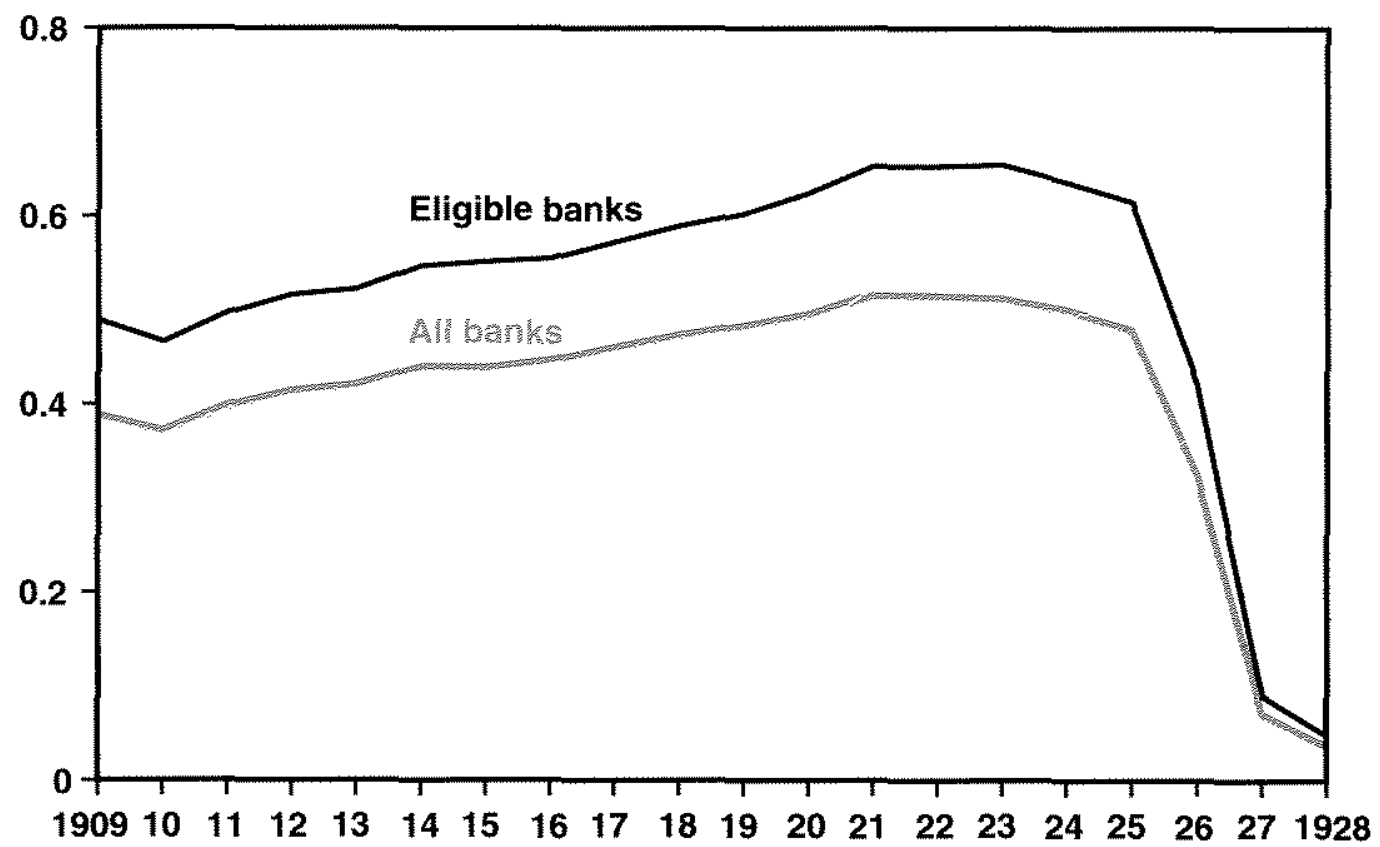

Figure 2

Proportion of Deposits in Insured Banks

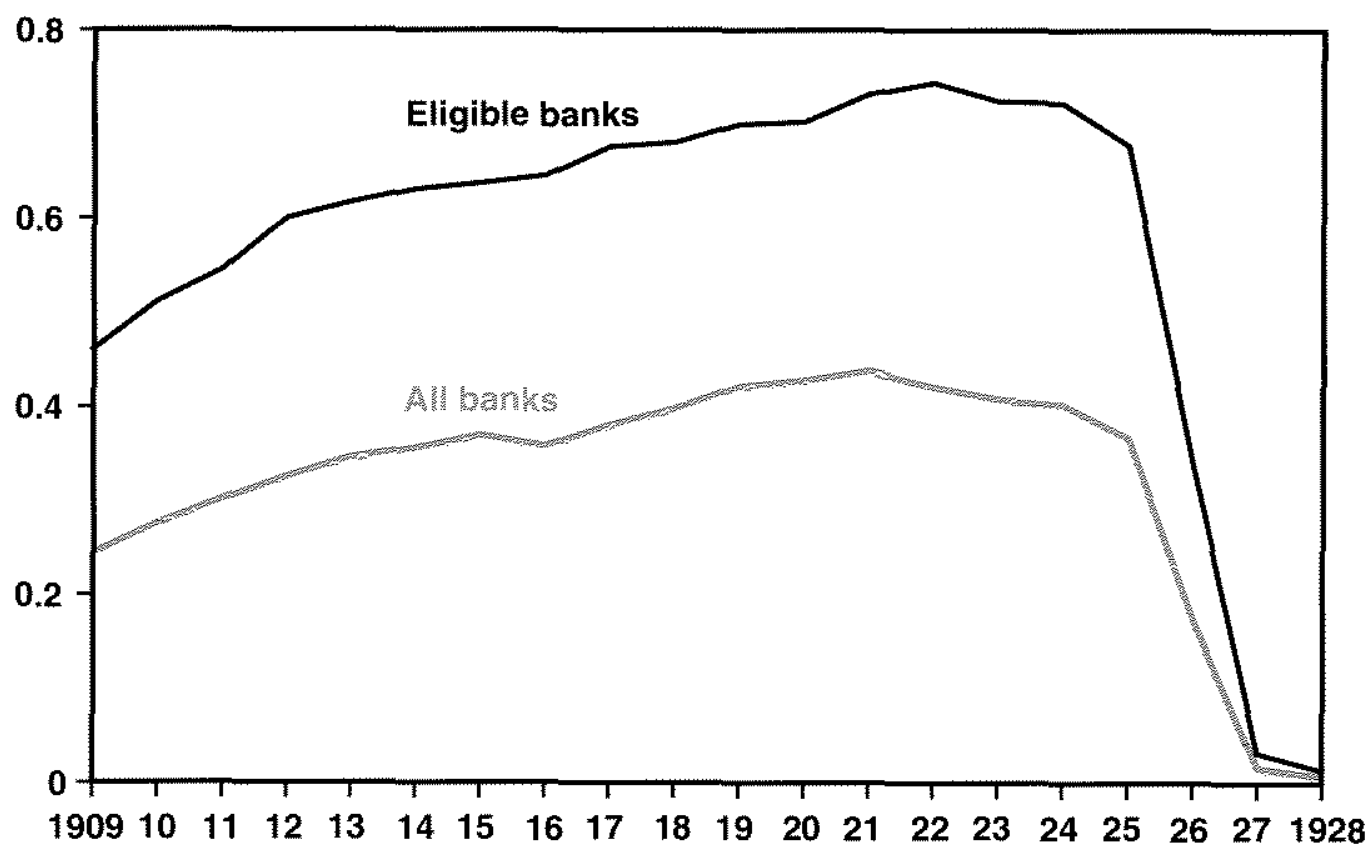


failure rate of insured banks might have been higher simply because risky banks were more likely to join the voluntary insurance system, that is, because of "adverse selection." Of course, both effects might have been present and contributed to the higher fatlure rate of insured banks.

The troubled history of the Kansas deposit insurance system raises the question of whether depositors expected an insufance payoff in the event of bank failure. If they did not, then depositors would have had an incentive to monitor their banks' activities and to demand the same terms from a member of the insurance system as from an uninsured bank with equal Hkelihood of fallure. Indeed, if depositors thought that insured banks had, on average, a higher probability of failure and that an insurance payoff was unlikely, then they would have had an incentive to transfer deposits from insured banks to uninsured banks. No doubt some depo" sitors did so, as the relative share of deposits in insured banks fell after 1921. Large numbers of depositors left their funds in insured banks, however, and because of the difficulty of assessing the extent of protection from deposit insur* ance at any point in time, might have expected at least pertial reimbursement in the event of bank failure. ${ }^{23}$

To investigate the relationship between deposit insurance and bank behavior, we compare various financial ratios of insured and uninsured banks in our sample in different years. Table 1 reports the mean capital/assets, deposits/assets and cash reserves/deposits ratios of insured and uninsured banks in our sample in each year for which data are avalable ${ }^{22}$ In general, insured banks maintained less capital relative to assets. than uninsured banks and, hence, were more likely to fail as a result of loan losses or other declines in asset values. The hypothesis that the mean capitalassets ratios of insured and uninsured banks are equal can be rejected (at the .10 level or better) in each year.
The greater reliance of insured banks on deposits is indicated by the fact that, except for 1924, insured banks had higher deposits assets ratios than uninsured banks. Insured banks also held fewer liquid assets ("reserves"), defined here as cash, cash items and the liabilities of other banks, relative to deposits than uninsured banks in 1910, 1914 and 1924. Thus, for some of the period, insured banks were less liquid than their uninsured competitors. We find the reserves/deposits ratio to be particularly useful for distinguishing failing and nonfailing banks. The comparatively low capitalassets and reserves/deposits ratios of insured banks indicate that they were more risky than unin" sured banks and, hence, the higher failure rate of insured banks is not surprising. We further examine the impact of deposit insurance on the probability of failure, and seek to identify other characteristics which distinguish fail* ing from nonfailing banks in the following sections.

\section{rill} 15205

The number of banks and total bank deposits grew rapidly throughout the United States in the first two decades of the 20 th century, espe. cially during the inflationary boom of World War I. Kansas experienced a 30 percent increase in the number of banks between 1910 and 1920 , when it had 1,096 state chartered banks, 266 national banks and 18 unincorporated banks (Kansas, 1920, and Bankers Encyclopedia Company, March 1921). After 1920 , the number of banks in the United States fell sharply, especially in the Midwest and the South, where waves of bank failures followed a collapse of commodity prices. Between June 1920 and January 1921 , an index of wholesale commodity prices fell from 167 to 114; by January 1922, it had fallen to 91 (Board of Governors, 1937, p. 174). Sharply lower incomes left many farmers who had borrowed to

\footnotetext{
21 Wheelock and Kumbhakar (1994) argue that before 1926 , depositors had a reasonable expectation of an insurance payoff, and show that deposit insurance enabled members of the insurance system to hold lower capital ratios than uninsured banks untit that year.

22The biennial reports of the state banking commissioner (Kansas, various years) provide balance sheet data for all state-chatered banks and trust companies on August 31 of each even-numbered year (except 1912 and 1916).
} 


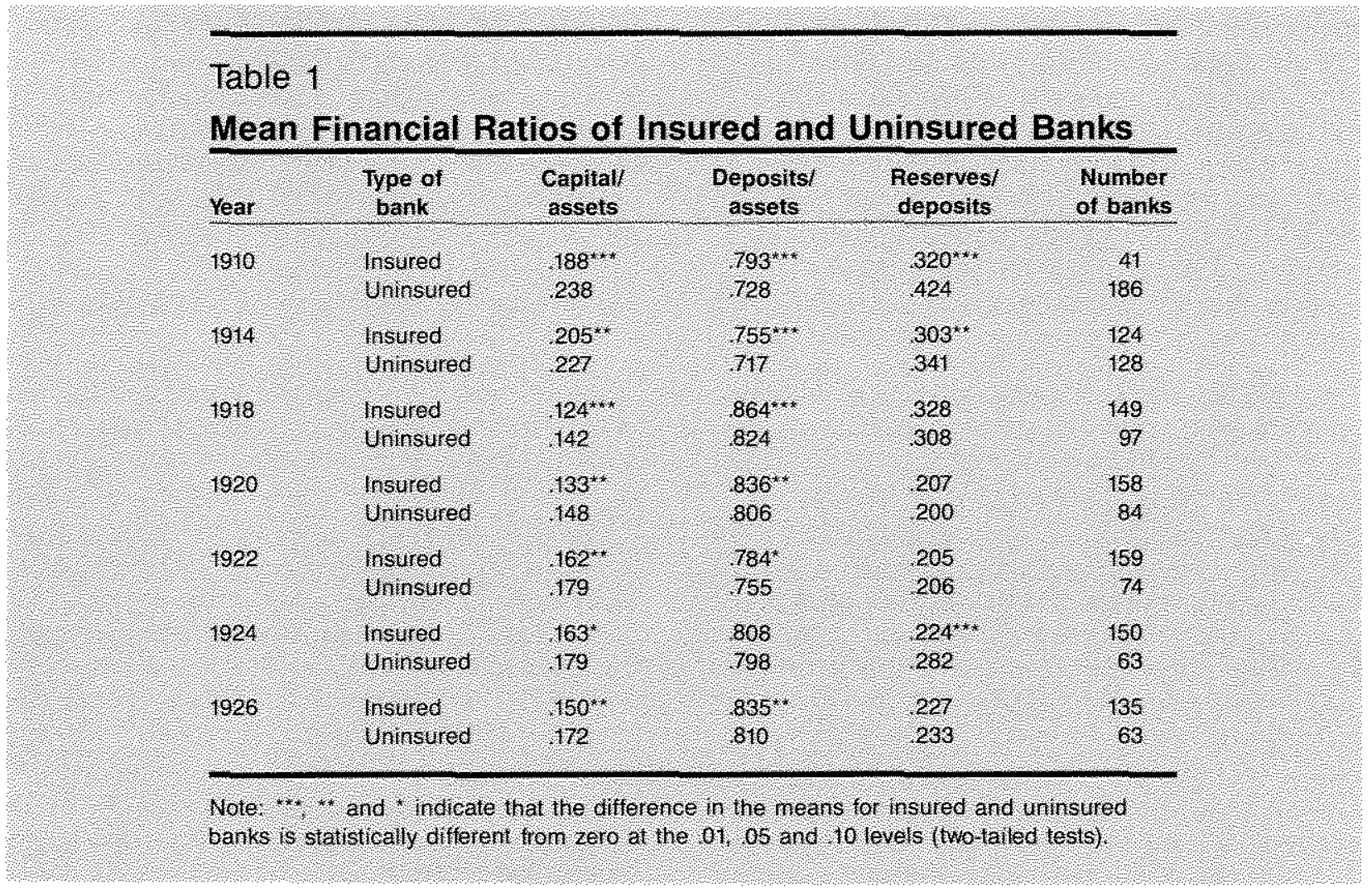

finance land acquistion and improvements be fore 1920 unable to repay their loans. Loan loss. es, in turn, caused the falure of many banks in commodity-producing regions, including 220 in Kansas between 1920 and 1929 .

The impact of agricultural distress on individual Kansas banks reflected the portfolio choices they had made prior to the collapse and as it unfolded. Between September 1920 and September 1926, 122 state-chartered Kansas banks failed, of those, 94 had been members of the insurance system (a 4.6 percent failure rate) and 28 had not (a 2.3 percent falure rate). By contrast, just six national banks failed a 0.8 percent falure ratel. Over the life of the insurance system, depositors of just 27 failed banks recovered the entire amount of their insured deposits, and those of two other banks received 93 and 95 percent of their deposits, respectively (Warburton, 1958, pp. 27-9). No insurance payments were made to depositors of 88 member banks that failed (FDrC, 1956, p. 58). On aver. age, holders of insured deposits received 53 per. cent of their funds from liquidation of bank assets and 18 percent from the deposit insurance find 7 percent of which came from the reorganization of one bank, the American State Bank of Wichita). The remaining 29 percent of insured deposits were never recovered.

The sharp increase in bank failures beginning in 1920 quickly swamped the resources of the Kansas deposit insurance fund. When a nember of the Kansas insurance system failed, its depositors were given interest-bearing centificates immediately upon closure, and received reimbursement only after the bank's assets had been entirely liquidated. It the proceeds from liquidation were insufficient to reimburse insured depositors, the insurance system was supposed to make up the difference. Depositors of the two banks that failed before 1920 were eventually fully rembursed, but inadequate insurance funds meant that depositors of most banks that failed after 1920 were not as fortunate.

Because depositors were not reimbursed until after liquidation of a failed bank's assets, the condition of the fund and the prospect that depositors of failed banks would eventually receive full reimbursement were difficult to determine at any point. The failure in June 1923 of the American State Bank of Wichita, the state's largest insured bank, presented the insur* 
ance system with its greatest challenge. Eventually, the bank was reorganized with other insured banks assuming $\$ 1.4$ million of the loss and depositors accepting; on average, 40 percent of their deposits in the form of stock in the new bank. The event marked a turning point in the history of the Kansas insurance system, however, as the number of banks and the deposits held in insured banks began to decline..$^{23}$

Although a special insurance assessment was collected in 1922 and insurance premiums were set at their legal maximums beginning in 1924 . losses from bank failures exceeded insurance system revenues from 1921 onward. In 1925, the state bank commissioner stopped making pay ments on all insurance claims, and in 1926 a state supreme court decision effectively ended the system. The court decision resulted from the refusal of seveal banks that had withdrawn from the insurance system to pay additional in. surance premiums. The court ruled that banks could withdraw without additional liability by simply giving up the bonds they had pledged to guarantee premium payments. This led many banks to withdraw and, by 1927 , insurance sys. tem membership had fallen to less than 10 percent of eligible banks.

Kansas appears to have suffered many of the problems that have been associated with the bank and S\&I debacle of the 1980s. In the 1980s, many depository institutions, especially insolvent S\&Ls, bid up deposil interest rates and grew rapidy by issuing deposits through brokers. ${ }^{2}$ In the 1920s, some banks appear to have evaded deposit interest rate ceilings in order to grow rapidly. In his report for 1922 (Kansas, 1992 , p. 5), the state bank commissioner also fell it desirable to limit deposit insurance to only the original holder of a deposit, and not to any as. signee. Supervision was also reported to have been weak in Kansas, especially during the worst failure years, and for a time state banking authorities permitted weak and insolvent banks to remain open rather than closing them immediately upon recognition of trouble $\left(W_{\mathrm{k}} \mathrm{r}\right.$. burton, 1958 , p. 19). Whether any such banks recovered is not known, but the lack of mention in the biennial reports of the state banking com missioner suggests that, like the attempts at forbearance during the 1980 s, the policy was probably not successful.

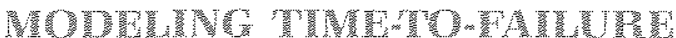

While many Kansas banks failed during the 1920s, a majority of banks survived the decade. What characteristics distinguish the survivors from the failures? To identify important characteristics of failing banks, we employ an econometric technique that explicitly models timeto-falture. The analysis of duration data is relatively new in economics. Engineers and biomedical scientists have analyzed time-to-failure for electrical and mechanical components of machinery and the survival times of subjects for many years, but economists have only recently begun to apply similar models, primarily in the area of labor economics with a focus on the duration of spells of unemployment. ${ }^{25}$ Although models developed to analyze duration data are sometimes called time-to-failure models, the event of interest need not be characterized as a "failure"; all that is necessary is that the event be well-defined.

Duration models differ from standard diserete choice models (such as probit or logit models) in that duration models use information about how long banks survive in the estimation of the instantaneous probability of falure for a given set of observations on the independent variables. Parameter estimates thus indicate whether an increase in the value of an individual independent variable will reduce or extend the expected time until failure occurs. By contrast, diserete choice models typically ignore information about the timing of fallures, and provide an estimate only of the probability of failure within a given interval of time. Discrete choice models treat all banks that fail during an interval the same, as they do all surviving banks. Thus, for example, a bank that fails on the first day of a two-year in-

2aSee Wheelock and Kumbhakar (1994) and Warburton (1958) for additional detail about this failure.

${ }^{24}$ See Kane (1989).

${ }^{25}$ Kiefer (1988) provides a good irtroduction to the analysis of duration data; Kalbfleisch and Prentice (1980) and Lan. caster (1990) provide more advanced treatments of the subject. 
terval is treated the same as a bank that fails on the last day, and a bank that survives the interval but fails one day after that period ends is treated the same as a bank that sur. vives an additional 10 years. Duration models explicitly incorporate such information, and thus yield more efficient parameter estimates. ${ }^{26}$ A detailed description of the duration model used in this article is presented in the appendix.

In the present application, we observe the charter date for each bank in our sample. For some banks, we observe a failure date, where failure is defined as the date on which the bank was ordered closed by the state banking commissioner. For the remaining banks, no failure date is observed if a bank had not failed by the end of our observation period (1928) or if it liq. uidated voluntarily, merged with another bank or switched to a federal charter. These observations are considered censored; information about these banks is available for part of their lives, but we do not observe them failing. Cen soring is common in duration data of all types and must be addressed within the statistical model used to examine the data.

Figure 3 illustrates the types of censoring that may occur in duration data. Assume that the interval over which banks are observed runs from time $t_{1}$ to $t_{2}$. The horizontal lines in the figure represent the time between the charter date and the date of failure for individual banks. Given the observation period $\left(t_{1}, t_{2}\right)$, the observation for Bank $A$ will be both left-and rightcensored. For this bank, neither the charter date nor the failure date occur within the observation interval. The observation for Bank $B$ will be left-censored; the charter date does not occur within the observation interval, but the failure date does. For Bank $\mathrm{C}$, both the charter and failure dates occur between $t_{1}$ and $t_{2}$, and so the observation is uncensored. Finally, the observation for Bank $\mathrm{D}$ will be right-censored; the charter date occurs within the observation interval, but the failure date occurs after $t_{2}$.

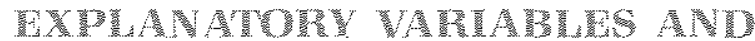

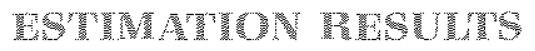

Other researchers have employed hazard and discrete choice models to identify characteristics that distinguish failing and surviving banks in a variety of settings. White (1984), for example, estimates a probit model to distinguish failing from nonfailing banks during the Banking Panic of 1930 . Wheelock (1992a) uses a similar model to study Kansas bank failures between 1920 and 1926. Both studies found that banks were more likely to fail, the lower their capilal/assets, sur. plus/loans, bonds/assets, reserves/deposits, or deposits/assets ratios. ${ }^{2}$ Banks were more likely to fail, the higher their loans/assets or shortterm borrowed funds/assets ratios. ${ }^{28}$

Many Kansas banks experienced significant loan losses following the collapse of agricultural prices and incomes in 1920-21, and banks with low capital/assets ratios were less well-cushioned against declines in the value of their assets. Banks with little cash and other reserve assets were less able to meet deposit withdrawals, and the smaller a bank's reserves/deposits ratio, the more likely it was to close due to illiquidity. Often a lack of cash was the first sign that a bank was in trouble, and would prompt closure by state banking authorities.

Just as a low level of reserves signaled trouble, so too did a heavy reliance on borrowed funds such as rediscounts of loans with other banks or with the Federal Reserve. Banks that relied heavily on borrowed funds to finance their operations, or that had to resort to borrowing because of loan losses or deposit withdrawals, appear to have been relatively more likely to fail.

Loans are generally the most risky and least liquid of bank assets, and the loan portfolios of the rural unit banks of Kansas were undoubtedly not well-diversified. Accordingly, the higher a bank's loans/assets ratio, the greater the likelihood that it would fail. On the other hand, banks with substantial bond holdings might
26While deriving a direct relationship between the paramezers of a duration model and a discrete choice model would be difficult, in principle one could integrate the hazard function estimated from a duration model to obtain the probability of failure within a given interval of time.

${ }^{27}$ Surplus refers to paid-in capital beyond the par value of a bank's stock plus undistributed profits. Reserves refer to cash, cash items and the liabilities of other banks.
${ }^{28}$ Borrowed funds consisted largely of rediscounted loans with the Federal Reserve or other banks. 


\section{Figure 3 \\ Possible Types of Censoring}

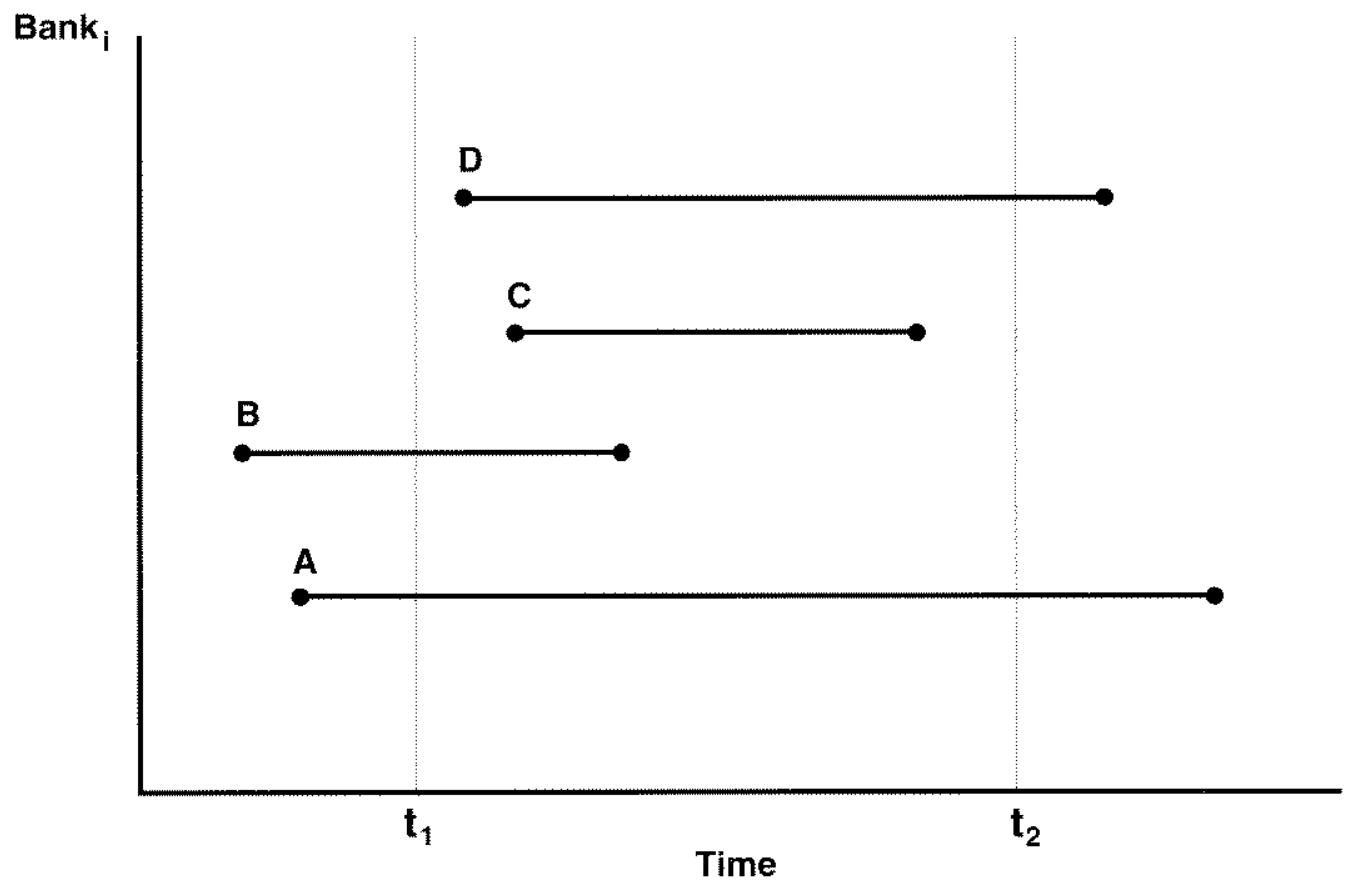

have been less likely to fail, especially since U.S. Govemment bonds and bonds of the state of Kansas and of Kansas municipalities probably comprised most of the bond holdings of Kansas banks in this era. ${ }^{39}$

Wheelock (1992b) includes bank size and a dummy variable indicating whether or not a bank was a member of the state deposit insurance system as additional explanatory variables. If larger banks were better diversified, or could capture economies of scale, they might have been less likely to fail. Wheelock found, however; no significant relationship between size and failure. Deposit insurance, on the other hand, did significantly affect the probability of fallure. Even though the capitalassets ratio and other measures of risk-taking should reflect whether or not a bank had insured deposits, the full impact of insurance may not be captured by observable variables. The deposit insurance dummy variable might reflect the incentive that insurance gives banks to hold riskier loans and investments than they otherwise would.

Wheelock (1992b) did not test for interaction effects between deposit insurance and the finarcial ratios. One might expect, however that the effect of a change in a financial ratio on the likelihood of failure would depend in part on whether or not the bank had deposit insurance. For example, the depositors of an insured bank might have been less concerned with a decline in the capitalassets ratio of their bank and, hence, less likely to demand a higher deposit in terest rate than depositors of an uninsured bank. The scope for risk-taking and, thus, the probability of fallare, resulting from a change

29 The state banking commissioner accepted only U.S.

Government, state of Kansas and Kansas municipal bonds

to guarantee payment of deposit insurance premiums.

Unfortunately, we do not have information on the composi-

tion of each bank's bond holdings. 
in a financial ratio might therefore depend on whether or not a bank was insured. We test this hypothesis here.

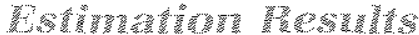

Our data consist of a panel of Kansas banks for which we have collected balance sheets and other information as of August 31 of each evennumbered year from 1910 to 1926 (except 1912 and 1916, when these data were not published). ${ }^{31}$ Our sample includes 259 banks (approximately one-fourth the total operating in 1914). ${ }^{31}$ Of these, 47 (18 percent) had failed by September 1, 1928. Banks that merged with other banks, liquidated voluntarily or switched to a federal charter are treated as censored on the date of merger or change in charter. Banks that did not fail or otherwise ceased operating prior to August 31, 1928, are treated as censored on that date.

In addition to the independent variables used by Wheelock (1992b), we include dummy variables for each interval of 1920-22, 1922-24, 1924-26 and $1926-28$ to investigate whether the probability of failure differed across periods for a given set of bank attributes. Only two banks in our sample failed before 1920 and, hence, we do not include dummies for those years. In one specification we also include interaction terms of deposit insurance and the financial ratios. ${ }^{32}$

Table 2 reports estimates of the failure model that include alternative combinations of explanatory variables. In column one, the coefficient on the capital/assets, bonds/assets and reserves/ deposits ratios indicate that the higher each of these ratios was, the less likely a bank was to fail. Better capitalized banks, and those with substantial bond holdings and significant reserves, could better absorb the shock of loan losses and deposit withdrawals accompanying the agricultural downturn in Kansas. Banks that had substantial borrowed funds relative to assets had a greater chance of failing while, contrary to expectations, it appears that the higher a bank's loan/assets ratio, the less likely it was to fail. This finding appears due to multicollinearity, however. The loans/assets ratio is highly correlated with the reserves/deposits ratio. If the latter is omitted, as in the specification reported in column two, the sign of the coefficient on the loans/assets ratio is positive, though not statistically significant.

The coefficient on deposit insurance is not statistically significant, suggesting that any effect that insurance had on the probability of failure is captured by its relationship with the financial ratios also included in the model. If the dum. mies for the biennial observation intervals are omitted, the coefficient on insurance is larger and statistically significant. It may be that the strain on the portfolios of all banks caused by the collapse of commodity prices overwhelmed the effect of deposit insurance on the unobserved portfolio risk of insured banks, which could explain why the coefficient on insurance is not significant when the time dummies are included. Not surprisingly, for given values of the financial ratios, banks were more likely to fail after the collapse of commodity prices and onset of severe agricultural distress in 1920. Finally, none of the coefficients on the interaction terms of deposit insurance and the financial ratios is statistically significant. Again, it appears that any impact of deposit insurance on the likelihood of failure is captured by differences in the financial ratios between insured and uninsured banks.

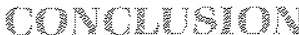

Researchers have blamed federal deposit insurance for contributing to the high numbers of bank and thrift failures and large deposit insurance payoffs since 1980. Unless insurance premiums increase proportionately with risk, banks will be encouraged to take greater risks than they otherwise would. This article presents

30The source of our data is Kansas (various years).

31We dropped seven banks because of missing data. Others fall out of the panel after failing, closing voluntarily, merging with other banks, or switching to a national charter.

${ }^{3}$ Few state-chartered Kansas banks were members of the Federal Reserve System during this era. None of the failed barks in our sample was a member, and so differences in supervisory agency or regulation, except those pertaining to deposit insurance, cannot explain variation in failure probabilities across banks. 
Table 2

\section{Failure Model Estimates}

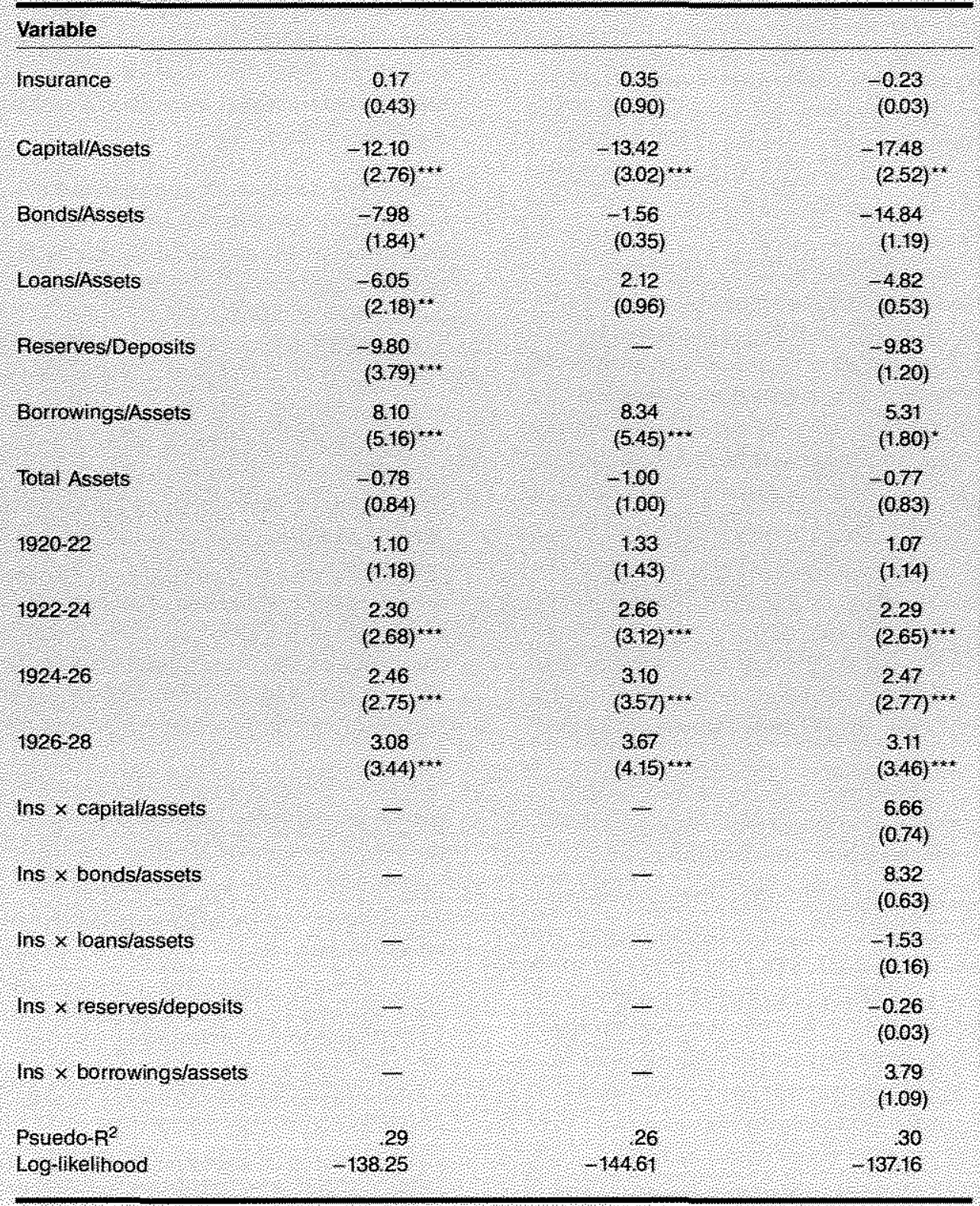

Notes Absolute values of $t$ statistics are in parentheses, 00 to and t indicate statstically significant at the 01,05 and 10 levels

some historical evidence of how deposit insurance can alter bank behavior and increase the likelihood that a bank will fail. As in the 1980s, when falling incomes in agricultural and energy. producing states caused large loan losses and led to many bank and thrift failures, a sharp decline in agricultural incomes in the early 1920 s caused the failure of many commercial banks in rural areas. Not all banks failed, however; in fact, most survived the collapse. Banks that carried deposit insurance had a higher rate of failure than other banks. Our findings, along with those of similar historical studies, show that insured banks were less well capitalized and less liquid than other banks. Estimates of a model of time-to-failure indicate that among banks in our sample, those with high ratios of capital to assets, reserves to 
deposits, large bond holdings relative to their total assets, or that relied little on borrowed funds, were less likely to fail. In short, conservatively managed banks were less likely to fail and, at the same time, banks that carried deposit insurance were more risky and, hence, more likely to fail than their uninsured competitors.

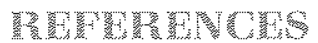

Alston, Lee J., Wayne A. Grove and David C. Wheelock. "Why Do Banks Fail? Evidence from the 1920s," Explorations in Economic History (1994, forthcoming).

American Bankers Association. The Guaranty of Bank Deposits (1933).

Anderson, Per K, and Richard D. Gill. "Cox's Regression Model for Counting Processes," Annals of Statistics (December 1982), pp. 1100-20.

Association of Reserve City Bankers. The Guaranty of Bank Deposits (1933).

Bankers Encyclopedia Compary. Polk's Bankers Encyclopedia (March 1921).

Board of Governors of the Federal Reserve System. All Bank Statistics, 1896-1955 (1959). Banking and Monetary Statistics, 1914-1941 (1943). Annual Report (1937).

Calomiris, Charles W. "Deposil Insurance: Lessons from the Record," Federal Reserve Bank of Chicago Economic Perspectives (May/June 1989), pp. 10-30.

Cooke, Thornton. "The Insurance of Bank Deposits in the West," Quarterly Journal of Economics (Nov. 1909), pp. 85-108.

Cox, David R. "Partial Likelihood," Biometrika (May/August, 1975), pp. 269-276

"Regression Models and Life Tables," Journal of the Royal Statistical Association (1972), pp. 187-220.

Efron, Bradley. "The Efficiency of Cox's Likelihood Function For Censored Data," Joumal of the American Statistical Association (September 1977), pp. 557-565.

Federal Deposit Insurance Corporation. Annual Report (1956).

Flood, Mark D. "The Great Deposit Insurance Debate," this Review (July/August 1992), pp. 51-77.

Golembe, Carter. "The Deposit Insurance Legislation of 1933: An Examination of its Antecedents and its Purposes," Politi cal Science Quarterly (June 1960), pp. 181-200.

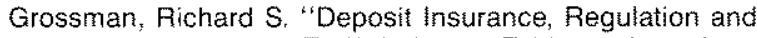
Moral Hazard in the Thrift Industry: Evidence from the 1930s," The American Economic Review (September 1992), pp. $800-21$.

Harger, Chartes Moreau. "An Experiment that Falled: What Kansas Learned by Trying to Guarantee Bank Deposits," Outlook (June 23, 1926), pp. 278-79.
Johansen, Soren. "An Extension of Cox's Regression Model," International Statistical Review (August 1983), pp. 165-74.

Kalbfleisch, J. D. and R. L. Prentice. The Statistical Analysis of Failure Time Data. John Witey and Sons, 1980.

Kane, Edward J. The S\&L Insurance Mess: How Did it Happen? The Urban Institute Press, 1989.

Kansas. Biennial Report of the Bank Commissioner (various years).

Kareken, John $H_{\text {. }}$, and Neil Wallace. "Deposit Insurance and Bank Regulation: A Partial-Equilibrium Exposition," Journal of Business (July 1978), pp. 413-38.

Keeley, Michael $\mathrm{C}$. "Deposit Insurance, Risk, and Market Power in Banking," The American Economic Review (December 1990), pp. 1183-1200.

Kiefer, Nicholas M. "Economic Duration Data and Hazard Functions:" Journal of Economic Literature (June 1988), pp. $646-79$.

Lancaster, Tony, The Analysis of Transition Data. Cambridge University Press, Inc., 1990.

Merton, Robert C. "An Analytic Derivation of the Cost of Deposit Insurance and Loan Guarantees;" Journal of Banking and Finance (June 1977), pp. 3-11.

Mishkin, Frederic S. "An Evaluation of the Treasury Plan for Banking Reform," Joumal of Economic Perspectives (Winter 1992), pp. 133-53.

O'Driscoll, Gerald P. "Bank Failures: The Deposit Insurance Connection," Contemporary Policy issues (April 1988), pp. $\$-12$.

Robb, Thomas B. The Guaranty of Bank Deposits. Houghton Mifftin Co., 1921.

Warburton, Clark. Deposit Guaranty in Kansas, unpublished manuscript, Federal Deposit insurance Corporation, 1958

Wheelock, David C. "Is the Banking Industry in Decline? Recent Trends and Future Prospects From a Historical Perspective," this Review (September/October 1993), pp. 3-22.

"Regulation and Bank Failures: New Evidence from the Agricultural Collapse of the 1920s," The Journal of Economic History (December 1992a), pp. 806-25.

"Deposit Insurance and Bank Failures: New Evidence from the 1920s," Economic Inquiry (July 1992b), pp. $530-43$.

, and Paul W. Wilson. "Explaining Bank Failure: Deposit Insurance, Regulation and Efficiency," working paper no. 93-002A, Federal Reserve Bank of St. Louis (1993).

, and Subal C. Kumbhakar. "'The Slack Banker Dances': Deposit Insurance and Risk-Taking in the Banking Collapse of the 1920s," Explorations in Economic History (1994 forthcoming).

White, Eugene N. "A Reinterpretation of the Banking Crisis of 1930," Journal of Economic History (March 1984), pp. 119-38. 


\section{Appendix \\ The Proportiona Tazar Iodel}

This appendix describes the proportional hazard model estimated in this article in some detail for interested readers who are unfamiliar with duration models, but have some understanding of econometrics or statistics. We wish to estimate the effect of deposit insurance and other variables on the probability of failure at particular times for the $n$ banks in our sample. Let $T_{i}, i=1, \ldots, n$, represent the failure time for the ith bank in our sample; where $T_{i}$ is not observed, we say that the observation is censored. Time is measured relative to the individual bank's charter date, with a zero value at the charter date. Hence, for each bank in the sample, the corresponding time scales will have different values for a given calendar time. If $T$ is a continuous random variable with a continuous probability distribution $f(t)$, where $t$ is a realiza * tion of $T$, then the cumulative probability is

(1) $\operatorname{Prob}(T<t)=F(t)=t_{0}^{l} f(u) d u$.

The function $F(t)$ gives the probability that a bank fails before time $t$ (subscripts are omitted where no ambiguity results). Alternatively, the same information may be expressed in terms of the survival function

(2) $S(t)=1-F(t)$,

which is merely $\operatorname{Prob}(T \geq t)$.

Given that a bank has survived until time $t$, what is the probability that it will fail during the next short interval of time, $\Delta$ ? The function characterizing this aspect of the problem is the hazard rate, given by

$$
\text { (3) } \begin{aligned}
\lambda(t) & =\lim _{\Delta \rightarrow 0} \frac{\operatorname{Prob}(t \leq T \leq t+\Delta \mid T \geq t)}{\Delta} \\
& =\lim _{\Delta \rightarrow(t)} \frac{F(t+\Delta)-F(t)}{\Delta S(t)} \\
& =\frac{f(t)}{S(t)} .
\end{aligned}
$$

The hazard function gives the instantaneous rate of failure per unit lime period at time $t$.

The density function $f(t)$, the cumblative density function $F(t)$, the survival tunction $S(t)$ and the hazard function $\lambda(t)$ each characterize the du- ration of banks. Furthermore, all four functions are related. From equations 2 and 3 , it follows that

(4) $\lambda(t)=\frac{-d \log S(t)}{d t}$

Also, rearranging terms in equation 3 yields

(5) $f(t)=S(t) \lambda(t)$

Another useful function is the integrated hazard function,

(6) $\Lambda(t)=\int_{0}^{t} \lambda(u) d u$.

Then, from equations 4 and 6 the survival function may be written as

(7) $S(t)=e^{-N(t)}$

and from equation 7 we have

(8) $\Lambda(t)=-\log S(t)$

Estimation of the failure time relationship re quires specifying a functional form for either $f(t), F(t), S(t), \lambda(t)$, or $\Lambda(t)$. Note that a functional form need only be specified for one of these functions; the relations in 1 and 4.8 will imply a functional form for the remaining functions.

We use the proportional hazard relationship developed by Cox (1972), where

(9) $\lambda\left(t[x, \beta)=\lambda_{0}(t) \mathrm{e}^{x \beta}\right.$,

where $x$ is a row vector of measured covariates and $\beta$ is a column vector of parameters with the appropriate dimensions. This model assumes a baseline hazard, $\lambda_{0}(t)$, which in principle amounts to an unidentified parameter for each bank in the sample. 'Thus, $\lambda_{0}(t)$ accounts for any unob. served heterogeneity among the banks that might otherwise bias the parameter estimates. The covariates in $x$ influence the overall hazard for each bank through the exponential terms in equation 9 the choice of an exponential form here is common throughout the literature on hazard estimation and simplifies the estimation problem relative to choices of other functionat forms). The model is semiparametric since the exponential in 9 is a parametric form, while the baseline hazard involves an unspecified form 
and, hence, is nomparametrie. Consequently, the model is more flexible than models in which the failure time distribution is assumed known except pertaps for a few scalar parameters.

Given the hazard specification in equation 9 , the corresponding survivor function (which gives the probability of survival up to time $t$ ) may be written as

(10) $S\left(t \mid x_{s} \beta\right)=\exp \left[-\lambda_{0}^{t}(u) e^{x \beta} d u\right]$

For uncensored observations with failure at time $T$, the contribution to the likelihood is $f(T \mid x)$; for observations censored at time $T$, the contribu. tion to the likelihood is $S(T \mid x)$, that is the probability of survival until time $T$.

Cox $(1972,1975)$ suggests a partial-likelihood approach which can be used to estimate the parameters of the hazard function in 9 . Assume, for the moment, that no observations are censored, and that the observations are ordered by their completed, untied durations such that $t_{8}<$ $t_{2}<\ldots<t_{n}$ ' The conditional probability that observation 1 fails at time $t$, given that any of the $n$ observations could have failed at time $t_{*}$, is

(11) $\frac{\lambda\left(t_{1} \mid x_{1}, \beta\right)}{\sum_{i=1}^{n} \lambda\left(t_{1} \mid x_{i}, \beta\right)}=\frac{e^{x_{1} \beta}}{\sum_{i=1}^{n} e^{x_{1} \beta}}$.

The equality results from the assumption of the proportional hazard in 9; the baseline hazard $\lambda_{i}(t)$ cancels out of the expression on the left in 11. The expression in 11 gives the contribution of the first observation to the partial likelihood. Analogously, the contribution of the $j$ th observation to the partial likelihood is

$\frac{e^{x_{j}^{\beta} \beta}}{\sum_{i=j}^{n+\infty} e^{n, \beta}}$

The partial likelihood is given by the product of the individual contributions and, hence, its $\log$ is

(12) $L(\beta)=\sum_{i=1}^{n}\left(\alpha_{i} \beta-\log \left[\sum_{i=1}^{n} \theta^{x \beta}\right]\right)$.

Andersen and Gill (1982) and Johansem (1983) show that the partial likelihood can be treated as an ordinary likelihood concentrated with respect to $\lambda_{i f}{ }^{3.3}$

The model represented by equation 12 can be easily adjusted to accommodate censoring in the data. For the data used in this study, each bank $i$ in the sample is observed at $J_{i}$ different times $t_{i t}<t_{i z}<\ldots<t_{i j,}$, with either failure or censoring occurring at time $t_{i j}$. Note that imes here refer not to calendar time, but to time relative to the date of charter for bank $i$ so that $t_{i o}=0$ where $t_{i \theta}$ is the date of charter for the ith bank. The balance sheet information used in $x$ corresponding to time $t_{i j}, j=1, \ldots,\left(J_{i}-1\right)$, are as sumed to reflect the position of bank $i$ over the interval $\left[t_{i i}, t_{i t i+1}\right)$. The model estimated in this paper is time-varying in the sense that covariates in $x$ are assumed constant for intervals of time $\left[t_{i j}, t_{i j i+1 j}\right)$, but may vary across different intervals. Thus, for the $i$ th bank there are $\left(J_{i}-1\right)$ observed intervals; the first $\left(J_{j}-2\right)$ are both leftand right-censored, and the last is left-censored and also right censored if falure time is not observed for the ith bank.

To accommodate the censoring in the data, let $x_{i}(j), i=1, \ldots, n, j=1, \ldots, J$ denote the vector of covariates for bank $i$ during period $j$. Covariates are fixed within a given period, but may vary over different periods. Let $d$ equal 1 for banks that are observed to fail at some time within the entire observation period, and zero otherwise. Assume that banks are ordered by increasing date of failure. Then, the log-partial likelihood becomes

(13) $L(\beta)=\sum_{i=1}^{n}\left(d_{i} x_{i}(J) \beta-\log \left[\sum_{k=1}^{n} e^{x_{i}, H, \beta}\right]\right)$

Kiefer (1988) suggests that the intuition behind the partial-likelihood approach used here is that, in the absence of any information about the baseline hazard, only the order of the durations provides information about the unknown parameters of the model. In both 12 and 13, the instantaneous probability of failure is normalized by the sum of instantaneous probabilities of failure for all other banks that could have failed at the same time as the ith bank.
Alternatively, one could specify a parametric form for the baseline hazard in equation 9 and maximize the corresponding likelihood function. Although the partial-likel hood approach avoids the need for an arbitrary parametric specification of the baseline hazard there is a loss of efficiency in the resulting estimates relative to those ob- tained by maximizing the full likethood. See Efror (1977) for a discussion of this efficiency lass. 